\title{
Testing Export-Led Growth in Bangladesh: An ARDL Bounds Test Approach
}

\author{
Biru Paksha Paul
}

\begin{abstract}
Existing literature on export-led growth for developing countries is voluminous but inconclusive. The emerging economy of Bangladesh is registering spectacular growth in both exports and output in recent decades. This scenario has sparked a rise in research on the export-output relationship for the country. The results are nevertheless ambiguous. In a study over the liberalized regime from 1979 to 2010, this study engages a relatively new method of the autoregressive distributive lag (ARDL) bounds test approach, and finds strong evidence on export-led growth for Bangladesh in both the long run and the short run. Imports, however, do not show any significant relationship with output. The trade reform that began in Bangladesh in the late 1970s appears to have benefited the country's economic growth.
\end{abstract}

Index Terms-ARDL bounds test, Bangladesh economy, export-led growth, level relationship, trade liberalization.

JEL Codes: F41, F43, C32, 053

\section{INTRODUCTION}

With the advent of trade liberalization in recent decades, the hypothesis of export-led growth has drawn widespread attention to research. Bangladesh, as a vibrant South Asian economy, has recently exhibited spectacular growth performance. The growth rates of its gross domestic product (GDP), imports, and exports remained above 5, 6, and 10 percent, respectively, over the last two decades [1]. This scenario has triggered a number of questions such as: 1) Is a significant part of Bangladesh's GDP growth export-led? 2) What is the import-output relationship? 3) Is export-led growth in Bangladesh, if any, a long-run or short-run phenomenon? This paper attempts to address these questions by examining Bangladesh's trade-output relationship in an autoregressive distributed lag (ARDL) bounds test approach, a relatively new method to cointegration.

The studies on export-led growth in Bangladesh are numerous, but the results are still inconclusive. The positive impact of exports on output in the short run is not surprising as exports enter the aggregate income equation [2]. In the long run, exports may affect growth through availing economies of scale, introducing incentives of improving the quality of the products, reducing inefficiencies, and finally, innovating new technology due to competitive pressure in the world market [3]-[6]. Since the main objective of this study is to examine export-led growth for Bangladesh, I present the most relevant studies on the trade-output

The manuscript received September 9, 2013; revised October 27, 2013.

Biru Paksha Paul is with the State University of New York at Cortland (SUNY Cortland) (e-mail: biru.paul@ cortland.edu). relationship for the country.

While [7] finds evidence of export-led growth in Bangladesh for the 1967-1986 period, [8] finds no significant effect of export growth on GDP growth over the 1971-1990 period. Reference [9] finds that export growth significantly increases economic growth through its positive impact on total factor productivity over the 1962-1992 period. Reference [10] finds no evidence of a long-term relationship between exports and economic growth over the 1962-1992 period. Reference [11] finds the evidence of export-led growth for Bangladesh in both the long and the short run over the 1974-1999 period. Reference [12] finds both long-run and short-term causality from income to exports over the 1972-2000 period.

Reference [13] finds unidirectional causality from exports to growth for the 1976-2003 period. Reference [14] shows that trade liberalization fosters export growth for the 19732003 period. Reference [15] works with 44 developing countries over the 1960-2002 period, and finds evidence on export-led growth for Bangladesh in the long run, not in the short-run. Reference [16] finds limited support for exportled growth over the 1976-2005 period. Reference [17] finds long-run evidence on export-led growth for the 1973-2008 period. Reference [18] is the only one that uses the ARDL approach like mine, and examines the contributions of exports, foreign direct investments, and remittances to GDP of South Asian countries. Based on a 1976-2006 sample, this work finds the evidence of cointegration among these variables in Bangladesh. The error correction term, however, is highly insignificant ( $p$-value 0.63 ), suggesting an unstable long-run equilibrium model.

When most papers in this respect find evidence on exportled growth in Bangladesh, they have three major shortcomings: omitting important variables, selecting inappropriate variables and samples, and indulging methodological deficiencies. Although GDP and exports are of primary importance in testing export-led growth, excluding imports can create omitted variable bias or misspecification error. Many studies overlook this issue. Some studies use the IIP to proxy GDP - an attempt inappropriate for a country like Bangladesh [19].

Of crucial importance is the issue of sample selection. After its independence in 1971, Bangladesh embarked on socialist planning, and the consequential trade controls were massive. After the regime change in 1975, the country slowly began to move towards privatization and the market economy. The exchange rate remained fixed until the late 1970s. In 1979, Bangladesh launched a managed exchange rate to promote exports in particular. In the same year, the ruling government won the parliamentary election and that legitimacy empowered the regime to continue its liberalization policies. Anti-export bias was reversed. The 
export promotion bureau was remodeled in 1979 to explore new areas of trade. Hence, the year of 1979 can be viewed as a beginning of trade liberalization in Bangladesh (see [20], [21] for details). Most studies ignored this point in sample selection. Many studies suffer from methodological deficiencies such as small sample and omitted variable bias, improper conversion of data frequency, conflicting results in the Johansen test, and insignificant error-correction model. My study overcomes these shortcomings, and adopts an efficient approach to measure both the long-run and shortrun export-income relationship in Bangladesh.

In a sample over the liberalized regime from 1979 to 2010, this study finds evidence on export-led growth for Bangladesh. The result is robust in that the effect of exports on output is positive and significant in both the long run and the short run. Imports, however, do not show any significant relationship with GDP. The exchange rate reform and export promotion efforts that began in the late 1970s appear to have benefited Bangladesh's growth.

\section{DATA AND Methodology}

The 2000-constant U.S. dollar values of GDP, exports, and imports have been collected from [1]. These series commence in 1979, the beginning of the liberalized regime, and end in 2009. Based on [22] and [23], I add observations for 2010. Although discarding the observations of 2010 does not make any difference in findings, I prefer to keep them to increase the degrees of freedom. Thus, the sample begins in 1979 and ends in 2010, as shown in Fig. 1.

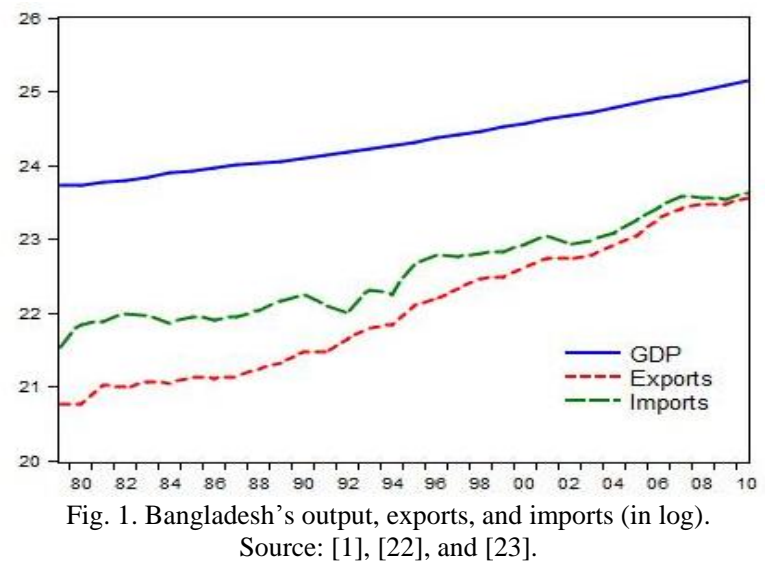

The studies that sequentially developed the ARDL bounds test approach include [24], [25], and [26]. There are numerous advantages in the ARDL method, which makes it more useful than others. With a small sample size, as is the case with mine, this method is more efficient than other techniques. In contrast, the Johansen cointegration technique, as in [27], requires larger samples for the results to be valid [28]. The simplicity of this ARDL bounds test method is appealing. As opposed to other multivariate cointegration techniques, it allows the cointegrating relationship to be estimated by the OLS method once the lag order of the model is identified. This asymptotic theory provides a simple univariate framework for testing the existence of a single level relationship between a variable and its regressors when it is not known with certainty whether the regressors are purely integrated of order one,
$I(0)$, purely $I(1)$, or mutually cointegrated. In contrast, the Johansen test can work only with nonstationary $I(1)$ series. Moreover, it is unnecessary that the order of integration of the underlying regressors be ascertained prior to testing the existence of a level relationship. Therefore, unlike typical applications of cointegration analysis, this method is not subject to this particular kind of pretesting problem.

Thus, a long-run relationship can be established with this technique irrespective of the time series properties of the variables in the model. Even when some of the model regressors are endogenous, the bounds testing approach generally provides unbiased long-run estimates and valid $t$ statistics [29], [30]. Moreover this approach provides a method of simultaneously assessing the short-run and the long-run effects of one variable on the other. At the same time, the ARDL has an appealing separation of short-and long-run effects [31]. The long-run relationship can be estimated in the following forms:

$$
\begin{aligned}
& y_{t}=\alpha_{1}+\beta_{1} x_{t}+\beta_{2} m_{t}+\varepsilon_{1 t} \\
& x_{t}=\alpha_{2}+\beta_{3} y_{t}+\beta_{4} m_{t}+\varepsilon_{2 t} \\
& m_{t}=\alpha_{3}+\beta_{5} y_{t}+\beta_{6} x_{t}+\varepsilon_{3 t}
\end{aligned}
$$

where $y$ denotes income/GDP/output, $x$ stands for exports, $m$ is imports, $\alpha_{i}(i=1 \ldots 3)$ stands for intercept terms, $\beta_{i}$ (i = 1...6) signifies coefficients on respective variables, and finally $\varepsilon_{i t}(i=1 \ldots 3)$ denotes error terms. To implement the bounds testing procedure, the following conditional ARDLerror correction models (ECMs) are presented, which correspond to (1) through (3), respectively:

$$
\begin{aligned}
& \Delta y_{t}=c_{1}+\pi_{1} y_{t-1}+\pi_{2} x_{t-1}+\pi_{3} m_{t-1}+\sum_{i=1}^{p} \theta_{i} \Delta y_{t-i}+\sum_{i=1}^{p} \phi_{i} \Delta x_{t-i}+\sum_{i=1}^{p} \delta_{i} \Delta m_{t-i}+u_{1 t}(4) \\
& \Delta x_{t}=c_{2}+\pi_{1} x_{t-1}+\pi_{2} y_{t-1}+\pi_{3} m_{t-1}+\sum_{i=1}^{p} \theta_{i} \Delta y_{t-i}+\sum_{i=1}^{p} \phi_{i} \Delta x_{t-i}+\sum_{i=1}^{p} \delta_{i} \Delta m_{t-i}+u_{2 t}(5) \\
& \Delta m_{t}=c_{3}+\pi_{1} m_{t-1}+\pi_{2} y_{t-1}+\pi_{3} x_{t-1}+\sum_{i=1}^{p} \theta_{i} \Delta y_{t-i}+\sum_{i=1}^{p} \phi_{i} \Delta x_{t-i}+\sum_{i=1}^{p} \delta_{i} \Delta m_{t-i}+u_{3 t}(6)
\end{aligned}
$$

where $\Delta$ denotes the first difference operator. $c_{i}(i=1 \ldots 3)$ shows constants, $\pi_{i}(i=1 \ldots 3)$ signifies coefficients on the lagged levels, $\theta_{i}, \phi_{i}$, and $\delta_{i}(i=1 \ldots p)$ denote coefficients on the lagged variables, and finally $u_{i}(i=1 \ldots 3)$ stands for error terms. $p$ signifies the maximum lag length, which is decided by the user. The researcher usually depends on literature and convention to determine the maximum lag length. The selection criteria such as Schwarz Bayesian Criterion (SBC) and Akaike Information Criterion (AIC) are mainly used to determine the order of the ARDL model. Given my sample size, I decide to use the SBC to determine the lag length of the ARDL, because the SBC chooses the most parsimonious model [32], [33].

Here $F$ and $W$ (Wald) statistics are employed to 'bounds test' for the existence of a long-run relationship where the null hypothesis states that the coefficients on the lagged levels are zero: $H_{0}: \pi_{1}=\pi_{2}=\pi_{3}=0$. This method provides lower and upper bound critical values where the lower 
bound critical values assume all variables are $I(0)$ while the upper bound critical values assume all variables are $I(1)$. If the calculated $F$ or $W$ statistic exceeds the upper bound, the null hypothesis of no cointegration can be rejected. If they fall below the lower bound, the null hypothesis of no longterm relationship cannot be rejected. However, if they fall within their respective bounds, inference would be inconclusive. Now estimating long-run coefficients and the ECM along with the short-run parameters becomes necessary. The sign of the error correction (EC) coefficient must be negative and significant to ensure convergence of the dynamics to the long-run equilibrium.

\section{ARDL AND ERRor CORRECTION ESTIMATIONS}

As discussed before, testing the variables for unit roots before the ARDL estimation is unnecessary, because this estimation can accommodate any variables, which are $I(1)$, $I(0)$, or mutually cointegrated. However, one limitation of the ARDL method is that it cannot be estimated with $I(2)$ series. Although the series of GDP, exports, and imports, as shown in Fig. 1, are most likely $I$ (1), I prefer to test them to make sure that none of them are $I(2)$.

TABLE I: PHIILIPS-PERRON Unit RoOT TeSTS WITH BANGLADESH'S OUTPUT, EXPORTS, AND IMPORTS: 1979-2010

\begin{tabular}{|c|c|c|c|c|c|}
\hline Variables: & \multicolumn{2}{|c|}{ In levels } & \multicolumn{2}{|c|}{ In first difference } & \multirow[b]{2}{*}{ Integration } \\
\hline & Model A & Model B & Model A & Model B & \\
\hline Output & $\begin{array}{c}7.39 \\
(1.00)\end{array}$ & $\begin{array}{l}-1.17 \\
(0.90)\end{array}$ & $\begin{array}{l}-3.91 \\
(0.01)\end{array}$ & $\begin{array}{l}-7.29 \\
(0.00)\end{array}$ & $\mathrm{I}(1)$ \\
\hline Exports & $\begin{array}{c}0.60 \\
(0.99)\end{array}$ & $\begin{array}{l}-2.20 \\
(0.47)\end{array}$ & $\begin{array}{l}-6.65 \\
(0.00)\end{array}$ & $\begin{array}{l}-6.80 \\
(0.00)\end{array}$ & $\mathrm{I}(1)$ \\
\hline Imports & $\begin{array}{l}-0.23 \\
(0.92)\end{array}$ & $\begin{array}{l}-2.43 \\
(0.36)\end{array}$ & $\begin{array}{l}-6.62 \\
(0.00)\end{array}$ & $\begin{array}{l}-7.65 \\
(0.00)\end{array}$ & $\mathrm{I}(1)$ \\
\hline
\end{tabular}

Note: Model A includes intercept, and Model B includes both intercept and trend. The null hypothesis states that the variable has a unit root. $p$ values are shown in the parentheses under each adjusted $t$-statistic. Source: [1], [22], and [23].

The Augmented Dickey-Fuller (ADF) test is widely used in this regard, as in [34] and [35]. Reference [36] proposed a modification of the Dickey-Fuller (DF) test and has developed a comprehensive theory of unit roots. The Phillips-Perron (PP) test has introduced a t-statistic on the unit-root coefficient in a DF regression, corrected for autocorrelation and heteroskedasticity. Formally, the power of a test is equal to the probability of rejecting a false null hypothesis. Monte Carlo simulations show that the power of the various DF tests can be very low. Reference [37:107] comments that the DF test does not have serious size distortions, but it is less powerful than the PP test. Reference [38] asserts that for low frequency data like mine the PP test appears to be more powerful than the ADF test. Accordingly, I adopt the PP methodology to test unit roots in the variables. Table I presents the results of the PhillipsPerron unit root tests with Bangladesh's GDP, exports and output. All the variables exhibit unit roots, whereas they become stationary in first differences. Thus, none of the series are (2), and they can be used in the ARDL bounds test method. The approach provides us with 95 percent critical bounds for the $F$ and $W$ (Wald) statistics, as shown in Table II.

TABLE II: ARDL COINTEGRATION TESTS WITH GDP, EXPORTS, AND IMPORTSIN BANGLADESH: 1979-2010.

\begin{tabular}{ccccccccc}
\hline $\begin{array}{c}\text { LHS } \\
\text { Variable }\end{array}$ & $\begin{array}{c}\text { Forcing } \\
\text { Variable }\end{array}$ & $\begin{array}{c}F- \\
\text { statis }\end{array}$ & $\begin{array}{c}95 \% \text { Critical } \\
\text { Bounds }\end{array}$ & $\begin{array}{c}W \text { - } \\
\text { statis }\end{array}$ & $\begin{array}{c}95 \% \text { Critical } \\
\text { Bounds }\end{array}$ & $\begin{array}{c}\text { Co- } \\
\text { integ- } \\
\text { ration }\end{array}$ \\
\hline$\Delta G D P_{t}$ & $\begin{array}{c}\text { exports, } \\
\text { imports }\end{array}$ & $\mathbf{1 2 . 2 1}$ & 4.29 & 5.49 & $\mathbf{3 6 . 6 2}$ & 12.87 & 16.46 & Positive \\
$\Delta$ exports $_{t} \begin{array}{c}\text { GDP, } \\
\text { imports }\end{array}$ & 2.36 & 4.29 & 5.49 & 7.08 & 12.87 & 16.46 & Absent \\
simports $_{t} \begin{array}{c}\text { GDP, } \\
\text { exports }\end{array}$ & 3.64 & 4.29 & 5.49 & 10.92 & 12.87 & 16.46 & Absent \\
\hline
\end{tabular}

Note: The null hypothesis for the $F$-test $W$-test is $\pi_{1}=\pi_{2}=\pi_{3}=0 . \pi_{1}, \pi_{2}$, and $\pi_{3}$ denote coefficients on lagged levels as per (4) through (6). Statistics are bold when significant at the

5 percent level. $\Delta$ denotes the first order difference operator. So urce: Same as in Table I.

The critical value bounds are computed by stochastic simulations using 20,000 replications [39]. The long-run level relationship is evident only when GDP is dependent on exports and imports. The $F$ statistic is significant at the 5 percent level, and so is the $W$ statistic in a consistent manner. Both statistics exceed the 95 percent upper bound, signifying cointegration among GDP, exports, and imports. Cointegration disappears when either export growth or import growth is placed in the LHS as per (4) and (5), suggesting no evidence of growth-led export or growthinduced import in the long run. The long-term feedback between exports and imports is also absent. Since both exports and imports act as forcing variables in the explanation of GDP, we are not sure at this point whether this implies export-led growth or import-led growth or a combination of both until we get the long run estimates.

TABLE III: LONGRUN COEFFICIENTS AND ERROR CORRECTION ESTIMATES FOR ARDL $(1,0,0)$ MODEL

Panel A: Long run coefficients with GDP(t) as dependent variable:

\begin{tabular}{|c|c|c|c|}
\hline & \multicolumn{3}{|c|}{ Regressors } \\
\hline & Constant & exports $(t)$ & imports (t) \\
\hline Coefficient & $12.983 * * *$ & $0.881 * * *$ & -0.319 \\
\hline Standard error & 2.633 & 0.274 & 0.317 \\
\hline
\end{tabular}

Panel B: Error correction model (ECM) estimations with $\triangle \mathrm{GDP}(\mathrm{t})$ as dependent variable:

\begin{tabular}{|c|c|c|c|c|}
\hline & \multicolumn{3}{|c|}{ Regressors } & \multirow[b]{2}{*}{$\begin{array}{l}\text { Adj. } \\
\mathrm{R}^{2}\end{array}$} \\
\hline & $\begin{array}{c}\Delta \text { exports } \\
\text { (t) }\end{array}$ & $\begin{array}{l}\Delta \text { imports } \\
\text { (t) }\end{array}$ & $\begin{array}{r}\text { ECM } \\
(\mathrm{t}-1)\end{array}$ & \\
\hline Coefficient & $0.045^{* *}$ & -0.016 & $-0.052^{*}$ & 0.63 \\
\hline Standard error & 0.018 & 0.016 & 0.028 & \\
\hline
\end{tabular}

Panel C: Diagnostic tests:

\begin{tabular}{lccllcc} 
& \multicolumn{2}{c}{ LM-Version } & & \multicolumn{2}{c}{ F-Version } \\
\cline { 2 - 3 } \cline { 5 - 6 } A: Serial Correlation & $\chi 2(1)=0.39$ & 0.53 & & & $F(1,25)=0.33$ & 0.57 \\
B: Functional Form & $\chi 2(1)=0.80$ & 0.37 & & $F(1,25)=0.68$ & 0.42 \\
C: Normality & $\chi 2(2)=4.02$ & 0.13 & & N/A & - \\
D: Heteroskedasticity & $\chi 2(1)=3.34$ & 0.07 & & $F(1,28)=3.51$ & 0.07 \\
\hline
\end{tabular}

Note: $\Delta$ denotes the first order difference operator. *,**, and $* * *$ indicate that the coefficients are significant at the $10 \%, 5 \%$, and $1 \%$ levels, respectively. In Panel C, the nulls are: (A) no serial correlation, (B) no functional-form misspecification, (C) no non-normal errors, and (D) no heteroskedasticity. Source: Same as in T able I.

Table II guides us to select (4) only for the ARDL. The 
SBC selects an ARDL (1, 0, 0) model, whose results are presented in Table III. Panel A of Table III gives the longrun coefficients of the ARDL estimations. The coefficient on exports is 0.88 , and is highly significant, suggesting that GDP rises by the 88 percent of the increase in exports in the long run. In contrast, the long-run impact of imports on GDP is negative but highly insignificant. While export-led growth for Bangladesh is quite evident, imports have no significant effect on output in the long run. The results of the error-correction model, as presented in Panel B of the same table, are quite consistent with that of Panel A. The short-run impact of exports on GDP is also positive and significant at the 5 percent level. Thus, exports foster GDP growth in Bangladesh both in the short run and long run. The role of imports in the error-correction model remains as insignificant as before. The error-correction term is negative as expected, but it is significant at the 10 percent level, instead of the conventional 5 percent level.

The negative sign before the error-correction term, 0.052 , suggests that the long-run equilibrium relation comes back to the steady state if the system is ever shocked. The value of the coefficient, however, is very low, suggesting that it will take a long time to restore the steady-state relation if the system is disturbed.

The estimated model reflects a fairly high level of goodness of fit, as shown in the adjusted R-squared value, 0.63. Panel $\mathrm{C}$ of the same table presents the diagnostic tests for the estimation. Given the results of the diagnostic tests in both $L M$ and $F$ versions, this estimated model is free of serial correlations, functional-form misspecification, nonnormal errors, and heteroskedasticity at the 5 percent level.

\section{CONCLUSION}

The recent growth performance of Bangladesh in both output and exports has sparked some questions such as: 1) Is a significant part of Bangladesh's GDP growth export-led? 2) Is export-led growth in Bangladesh, if any, a long-run or short-term phenomenon? 3) Is there any feedback between GDP and imports? My paper addresses these questions in an ARDL bounds test approach. The results of the studies in this respect are still inconclusive. This paper fills that gap by overcoming the shortcomings of sample selection and methodology that persisted in most previous papers.

In a study over the liberalized regime from 1979 to 2010 , this work finds evidence on export-led growth for Bangladesh. The result is valid in both the long run and the short run. Imports, however, do not have any significant relationship with GDP. The trade reform and export promotion agenda that commenced in the late 1970s appear to have benefited Bangladesh's growth. This finding of export-led growth for Bangladesh has policy implications for other developing nations that aspire to grow fast but confront dilemmas with trade liberalization and economic openness.

This paper raises some additional questions: 1) Why is not the feedback between GDP and import significant? 2) How do we estimate the import demand function for Bangladesh? 3) Is export-led growth also evident in other South Asian countries? These questions are left for future research.

\section{ACKNOWLEDGMENT}

I am thankful to Christopher Hanes, Daniel Henderson, and Urbashee Paul for their valuable comments. My special thanks go to Anupam Das and Gazi Salah Uddin for their resource and data support. Contact: biru.paul@ cortland.edu, Tel: 1-607 7534110 .

\section{REFERENCES}

[1] WB, World Development Indicators 2010 CD-ROM, World Bank, Washington DC, 2010.

[2] G. Feder, "On exports and economic growth," Journal of Development Economics, vol. 12, pp. 59-73, 1982.

[3] B. Balassa, "Exports and Economic Growth: Further Evidence," Journal of Development Economics, vol. 5, pp. 181-189, 1978.

[4] J. N. Bhagwati and T. N. Srinivasan, "Trade policy and development," in International Economic Policy: Theory and Evidence, R. Dornbusch, and J. A. Frenkel, Eds. Johns Hopkins University Press, 1978, pp. 1-38.

[5] W. G. Tyler, "Growth and export expansion in developing countries: some empirical evidence," Journal of Development Economics, vol. 9, pp. 121-130, 1981.

[6] D. Rodrik, "Closing the technology gap: does trade liberalization really help?" NBER WP 2654, 1988.

[7] S. Dodaro, "Exports and growth: A reconsideration of causality," Journal of Developing Areas, vol. 27, pp. 245-278, 1993.

[8] M. N. Islam and M. Iftekharuzzaman, "Exports-Growth Nexus in a Small Open Economy: The Case of Bangladesh," in the Economy of Bangladesh: Problems and Prospects, C. E. Weis and A. Wahid, Eds., Praeger Publishing, CT, 1996, pp. 237-246.

[9] S. Begum, and A. F. M. Shamsuddin, "Exports and economic growth in Bangladesh," Journal of Development Studies, vol. 35, pp. 89-114, 1998.

[10] A. Razzaque, B. H. Khondker, N. Ahmed, and M. K. Mujeri, "Trade liberalization and economic growth: Empirical evidence on Bangladesh," MAP technical paper, Bangladesh Institute of Development Studies, 2003.

[11] M. A. Hossain, and N. D. Karunaratne, "Exports and economic growth in Bangladesh: Has manufacturing exports become a new engine of export-led growth?" International Trade Journal, vol. 18 , no. 4, pp. 303-334, 2004

[12] J. Love and R. Chandra, "Export-led growth in Bangladesh in a multivariate VAR framework," Journal of Asian Economics, vol. 15, pp. 1155-1168, 2005.

[13] K. A. A. Mamun and H. K. Nath, "Export-led growth in Bangladesh: A time series analysis," Applied Economics Letters, vol. 12, pp. 361364, 2005.

[14] P. J. Dawson, "The export-income relationship and trade liberalization in Bangladesh," Journal of Policy Modeling, vol. 28, pp. 889-896, 2006.

[15] M. B. Oskooee and M. Oyolola, "Export growth and output growth: An application of bounds testing approach," Journal of Economics and Finance, vol. 31, no. 1, pp. 1-11, 2007.

[16] H. A. Ahmed and M. G. S. Uddin, "Export, imports, remittance and growth in Bangladesh: An empirical analysis," Trade and Development Review, vol. 2, no. 2, pp. 79-92, 2009.

[17] M. A. Hossain, L. Haseen, and N. Jabin, "Dynamics and causality among exports, imports and income in Bangladesh," Bangladesh Development Studies, vol. 32, no. 2, pp. 101-113, 2009.

[18] M. Rahman, "Contributions of exports, FDI, and expatriates' remittances to real GDP of Bangladesh, India, Pakistan, and Sri Lanka," Southwestern Economic Review, vol. 36, pp. 141-153, Spring, 2009.

[19] P. Dua and A. Banerji, "An indicator approach to business and growth rate cycles: The case of India," Indian Economic Review, vol. 36, no. 1 , pp. 55-78, 2001

[20] N. Aziz. (2008). The role of exchange rate in trade balance: Empirics from Bangladesh. Working paper, University of Birmingham. [Online]. $\quad$ pp. 1-25. Available: http://www.soegw.org/files/program/99-Aziz.pdf

[21] S. A. Choudhury. (2008). Prioritizing development: Impact of trade policy: Bangladesh perspective. [Online]. Available: http://www.centad.org/download/PPP\%20fin_IV\%20S\%20A\%20Con f_New\%20Delhi\%20\%2017_18\%20Dec\%202008.ppt(14-1208,04.15).pdf

[22] MoF. (2010a). Macro Scenario-Bangladesh ministry of finance. [Online]. Available: http://www.mof.gov.bd/en/budget/me/ 
mes_en july_sep_10.pdf?phpMyAdmin=GqNisTr562C5oxdV\%2CEr uqlWwoM5andphpMyAdmin=XRGktGpDJ7v31TJLuZ5xtAQmRx9

[23] MoF. (2010b). Medium-Term macroeconomic framework: Bangladesh ministry of finance. [Online]. Available: http://www.mof.gov.bd/en/budget/10_11/mtbf/en/Chapter_II.pdf?php MyAdmin=GqNisTr562C5oxdV,EruqlWwoM5, 22.

[24] M. H. Pesaran and B. Pesaran, Working with Microfit 4.0: Interactive Econometric Analysis, Oxford University Press, 1997.

[25] M. H. Pesaran and Y. Shin, "An autoregressive distributed lag modeling approach to cointegration analysis," in Econometrics and Economic Theory in the 20th Century: The Ragnar Frisch Centennial Symposium, S. Strom, Ed. Cambridge University Press, 1999, pp. 371-413.

[26] M. H. Pesaran, Y. Shin, and R. J. Smith, "Bounds testing approaches to the analysis of level relationships," Journal of Applied Econometrics, vol. 16, pp. 289-326, 2001.

[27] S. Johansen and K. Juselius, "Maximum likelihood estimation and inference on cointegration with application to the demand for money," Oxford Bulletin of Economics and Statistics, vol. 52, pp. 169-209, 1990.

[28] S. Ghatak and J. Siddiki, "The use of ARDL approach in estimating virtual exchange rates in India," Journal of Applied Statistics, vol. 28 pp. 573-583, 2001.

[29] P. K. Narayan, "The saving and investment nexus for China: evidence from cointegration Tests," Applied Economics, vol. 37, no. 17, pp. 1979-1990, 2005.

[30] N. M. Odhiambo, "Energy consumption and economic growth nexus in Tanzania: An ARDL bounds testing approach," Energy Policy, vol. 37 , no. 2, pp. 617-622, 2008

[31] I. Bentzen and T. Engsted, "A revival of the autoregressive distributed lag model in estimating energy demand relationships," Energy, vol. 26, pp. 45-55, 2001.

[32] W. Enders, Applied Econometric Time Series, 3e, Wiley, NJ, 2010.

[33] H. Lutkepohl, "Comparison of criteria for estimating the orders of a vector autoregressive process," Journal of Time Series Analysis, vol. 6, pp. 35-52, 1985

[34] D. Dickey, and W. A. Fuller, "Distribution of the Estimates for Autoregressive Time Series with a Unit Root," Journal of the American Statistical Association, vol. 74, pp. 427-431, 1979.

[35] D. Dickey and W. A. Fuller, "Likelihood ratio statistics for autoregressive time series with a unit root," Econometrica, vol. 49, pp. 1057-72, 1981.
[36] P. C. Phillips and P. Perron, "Testing for a Unit Root in Time Series Regression," Biometrika, vol. 75, no. 2, pp. 335-46, 1988.

[37] G. S. Maddala and I. M. Kim, Unit Roots, Cointegration, and Structural Change, Cambridge University Press, 1998.

[38] I. Choi and B. Chung, "Sampling Frequency and the Power of Tests for a Unit Root: A Simulation Study"” Economics Letters, vol. 49, pp. 131-36, 1995

[39] B. Pesaran and M. H. Pesaran, Time Series Econometrics using Microfit 5.0, Oxford University Press, 2009.

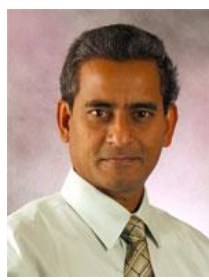

Biru Paksha Paul was born in Bangladesh in 1963 He received his B.S.S. (Honors) and M.S.S. both in economics from the University of Dhaka in 1986 and 1989, respectively. He earned his M.B.A. in finance from the University of Technology-Sydney in 1999. $\mathrm{He}$ received his M.A. in applied economics from the State University of New York at Binghamton in 2004. He received his Ph.D. in economics from the same university in 2007.

$\mathrm{He}$ is now serving as an associate professor of economics at the State University of New York at Cortland (SUNY Cortland) where he joined in 2007. He teaches macroeconomics and finance by relating theories to his twelve-year industry experience in banking and economic journalism. He worked as a consultant at Bangladesh's Central Bank, Ministry of Finance, and the UNDP. His papers have been accepted in numerous journals such as the Journal of Asian Economics, Journal of Quantitative Economics, Energy Economics, Indian Economic Review, and International Review of Economics. He has published one book on Indian business cycles and inflation. His research interest focuses on macroeconomic policy and economic growth of developing economies.

Dr. Paul is a life member of Bangladesh Economic Association. He received SUNY Cortland Award for excellence in research and scholarship in 2009 . 